N. Imamverdiyev', Dr. Sci. (Geol.-Min.), Prof., E-mail: inazim17@yahoo.com;

V. Baba-zadeh ${ }^{1}$, Dr. Sci. (Geol.-Min.), Prof.,

E-mail: vbabazade1938@mail.ru;

S. Mursalov ${ }^{1,2}$, Mining geology,

E-mail: samir.m.s@mail.ru;

A. Valiyev 1,2, PhD, Exploration Geology Manager, E-mail: velizade_anar@yahoo.com;

M. Mansurov ${ }^{1}$, Cand. Sci. (Geol.-Min.), Assist. Prof.,

E-mail: mamoy_mansurov@mail.ru;

A. Ismayilova', Cand. Sci. (Geol.-Min.), Assist. Prof.,

E-mail: aygun46 @mail.ru;

${ }^{1}$ Baku State University, 23 Z. Khalilov Str., Baku, AZ1148, Republic of Azerbaijan;

${ }^{2}$ Azerbaijan International Mining Company Limited, 20 Huseyn Javid Ave., 520, Baku, AZ1073, Republic of Azerbaijan

\title{
PROSPECTS OF NEWLY DISCOVERED UGUR AREA IN THE NORTHWEST OF THE GEDABEY ORE DISTRICT (LESSER CAUCASUS, AZERBAIJAN)
}

\begin{abstract}
(Представлено членом редакційної коледії д-ром геол. наук, проф. В.А. Михайловим)
The article describes Ugur exploration area located in Gedabey Ore District of the Lesser Caucasus in NW of Azerbaijan. Results of trenches and channels sampling on the surface, RC bore holes and summary of significant drill intercepts $(>0.29 \mathrm{ppm}$ Au) of Ugur Exploration area are presented. It has been established that The deposit is enlarged by highly gold-silver result of surface outcrop rock chip samples over an area of $2.5 \mathrm{kms}$ North-South by $2 \mathrm{kms}$ East-West, with the Reza gold deposit located in the central part. Out of metallic minerals crystalline hematite was observed. On surface intensive barite and barite-hematite vein and veinlets, also gossan zones were observed. The main mineralization zones have been sampled in three trenches at a distance up to $270 \mathrm{~m}$ by trenches \#1, \#2 and \#3 and received positive results for gold and silver. Also there have taken approximately 550 samples from outcrop \#1 and \#2. On the main orebody at surface centre there occured secondary quartzites with vein-veinlets barite-hematite mineralization over which there remain accumulations of hydrous ferric oxides cementing breccias of quartz and quartzites. And in erosion parts "reddish mass" being oxidation product of stock and stockverk hematite ores were observed. Representing typical gossans, these accumulations by the data of trenches for thickness about 5-10 m contain gold 0.3-2.0 ppm and silver 1.0-15.0 ppm. Ten diamond drill holes, named UGDD 01-10 were drilled in the center part of the deposit. The drill holes were sampled mainly in 1 meter lengths from the top of the hole to the bottom. The core samples were marked and placed into standard boxes.

Significant intervals of weighted averages greater than $0.29 \mathrm{ppm}$ over down hole intervals of 1 metres or greater $(>0.29 \mathrm{ppm}$ Au and $>0.9 \mathrm{~m}$ ) are summarized in table 3 below. In conclusion, the outcropping alteration at the deposit is typical of the upper steam-heated levels of high-sulfidation epithermal (HSE) deposits, which in most mineralized systems of this type, may cap higher-grade gold mineralization which is hosted by underlying vuggy and oxide zones.
\end{abstract}

Keywords: Ugur exploration area, prospects, mineralization zones, content of Au, Ag, Cu, Zn, Gedabey Ore District, Lesser Caucasus.

Formulation of the problem. In spite of the fact that the ore region is well studied, a number of issues, including the assessment of perceptions of offenses and deep horizons of the private Gedabak field, the study of modern geological and geochemical methods of other ore beds and manifestations in the region is carried out.

Ore district belongs to the Lok-Karabakh island of the Jurassic - Cretaceous age, formed by subduction of the Tetis Ocean to the Eurasian Caucasus in the Tetis metallogenic belt. The results of recent geological exploration and research activities in the Gedabak Ore region are high-sulfidation type (high sulfidation) of the Gedabey deposit, with high sulfidation, and the Au-Ag-Zn$\mathrm{Pb}$ filtration of the Gadir and Ugur deposits near it. Low sulfidation bedrock hopes to discover new porphyryepithermal ore deposits as part of a single epithermal system of the ore region. The location of gold-copperporphyry ores on the Gedabey deposit by experts as a "Gedabey copper deposit" in the Lesser Caucasus can be a promising criterion for the unique, non-ferrous and rare metals in the ore region.

The purpose of the work is to identify the regularities of the bed and manifestations of the Gedabey ore region using modern complex geological research methods, and to develop predictive search criteria to identify new perspective areas.

During the implementation of the article, maps were drawn based on the data of a company (Samir Mursalaov), and results of chemical and geochemical analyzes were used. Macro and micronutrient analysis (over 500 micronutrients, including $\mathrm{Au}, \mathrm{Ag}, \mathrm{Cu}$ ) was performed by
X-ray fluorescence (XRF) laboratory at SGS Mineral Services UK LTD in Ontario.

The article considers new data on the contents of $\mathrm{Au}$, $\mathrm{Ag}, \mathrm{Cu}, \mathrm{Zn}$ taken from trenches and wells in these deposits. This article describes Ugur exploration area - Reza gold deposit, and some mineralization areas (Gyzyldjadag, Shah Yatag, Yukhari Narzan and Dashbulag) which can be of interest from commercial point of view for future.

Geology. Gedabey ore district is located in the territory of Shamkir uplift of the Lok-Karabakh island arc volcanic structural-formation zone in the Lesser Caucasus Megaanticlinorium. The ore region has a complex geological structure, and it has become complex with the intrusive masses and breaking structures of different ages and different composition. Lower Bajocian is essentially composed of an uneven succession of diabase and andesite covers, agglomerate tuffs, tuff-gravelites and siltstones. Tuff facies of the Lower Bajocian were exposed to strong metamorphism (skarn alteration and hornfelsing) as a result of the impact of Upper Bajocian volcanism and intrusives of Upper Jurassic age. Only subvolcanic facie of the Upper Bajocian in the Gedabey mine has been studied (rhyolite and rhyodacite, quartz-porphyry). Rocks related to the Bathonian stage have developed mainly in the northern and southern edges of Shamkir uplift.

Gedabey ore district and Shamkir uplift in general is complex in terms of its tectonic structure and its magmatism is complex too. Magmatic processes in this region have occurred intensely. There are 3 phases of magmatism in the ore area: 1-Bajocian phases, 2-Bathonian phases, 3-Upper Jurassic phases (Abdullaev et al.,1988) (Fig. 1). 


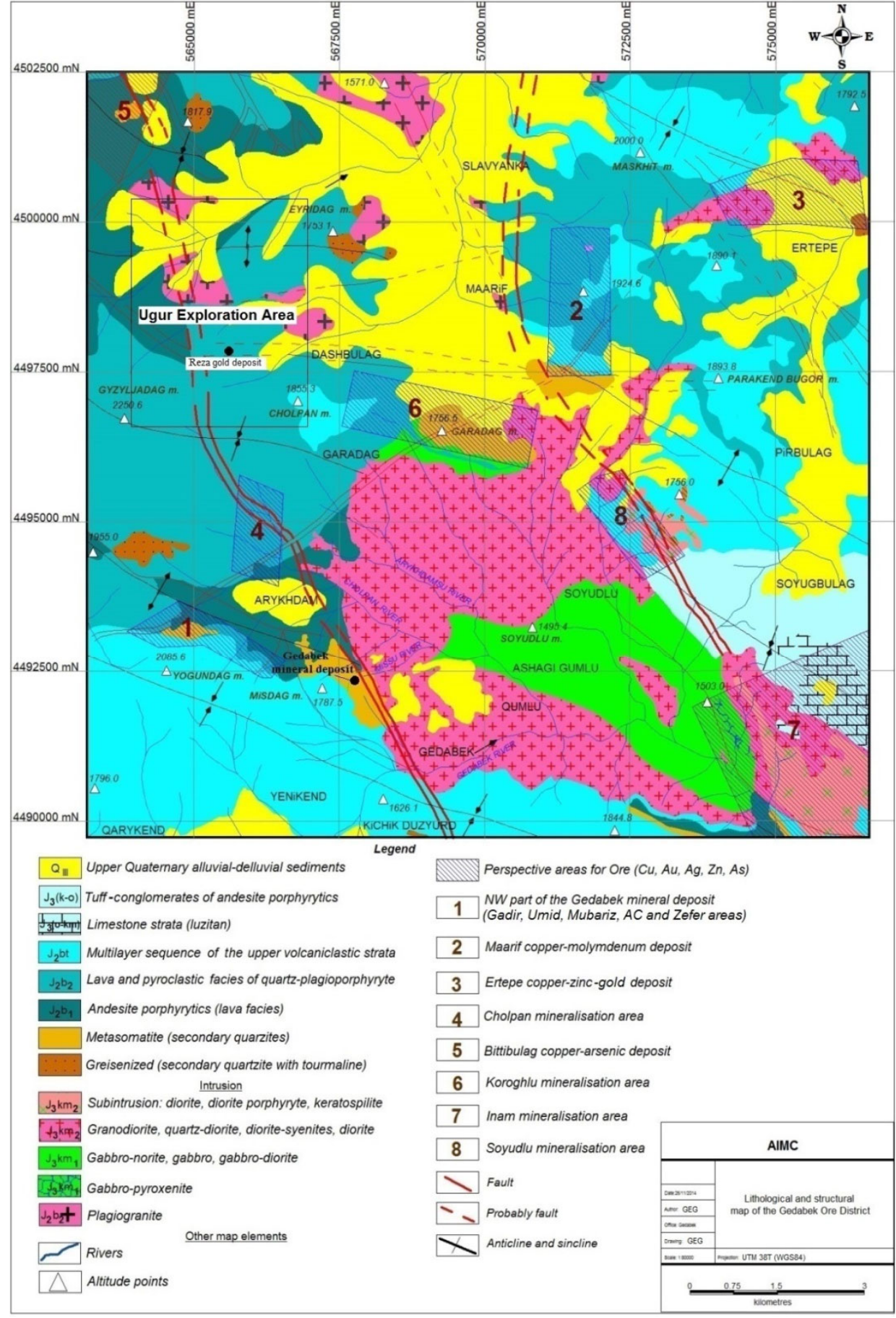

Fig. 1. Lithological-structural map of the Gedabey Ore District (perspective areas for $\mathrm{Cu}, \mathrm{Au}, \mathrm{Ag}, \mathrm{Zn} \& \mathrm{As}$ )

The Bajocian phase is divided into two autonomous sub-stages:

Lower Bajocian age rocks - intermediate and basic composition pyroclastic volcanic and volcanic disturbed rocks occupy the central portion of Shamkir uplift, and have become complex with intrusive and subvolcanic complexes and breaking structures of different ages, morphology.

Acid composition products of the Upper Bajocian magmatism are represented very broadly by all facies within Gedabey ore district. It can be considered that the magmatic center of the Upper Bajocian period is located in the Shamkir uplift.

Andesite, partially andesite-basalt composition products of the Bathonian phase of magmatism, as well as various composition pyroclastic materials and lava flows Upper Jurassic phase are spread mainly in the sidelines of Shamkir uplift. Along the breaking structures and in the areas between them, rocks along micro cracks have become strongly quartizated, kaolinized, sericitized and in most cases changed to secondary quartzite. Breaking structures have not caused Lower Bajocian rocks to become too complex. The main complexity were generated by subvolcanic masses of rhyolite, rhyodacite and quartzporphyry composition of Upper Bajocian age which occurred along the Gedabey-Bittibulag depth fault and which began to cool down in the area close to the surface (Baba-zadeh, Abdullayeva, 2012).

Rhyolites and rhyodacites changed to various types of quartzite, and the surrounding rocks changed into quartzite, skarn rocks and hornstones depending upon petrographic, mineralogical and lithological compositions. However, the processes mentioned above did not occur all through the 
subvolcanic masses and contact rocks. These processes occurred in such areas where there was a constant contact (open channel or open contact zone) between the subvolcano and magmatic source. One of such areas was the Misdag area in which Gedabey mineral deposit (mine) is located.

The NW part of Gedabey ore district is located along Gedabey-Bittibulag deeper fault, from the Yogundag Mountain area to Bittibulag copper-arsenic deposit. This area with respect to tectonics and metallogenic is confined to volcano-plutonic structure of Shamkir uplift of LokKarabakh structure-formation, Lesser Caucasus metallogenic zone (Adamia et al., 2011). The ore perspective areas (porphyry, high and low sulfidation epithermal deposit types) are embedded in cone-shaped Mountain Yogundag at elevation $2085 \mathrm{~m}$ and Gyzyldjadag at altitude $2250.6 \mathrm{~m}$.

The study of the Gedabey ore district was carried out by many geologists. They examined mainly the geology and magmatism of the region (Abdullaev et al., 1988; Abdullaev, 2018; Baba-zadeh, 2005; Baba-zadeh, Abdullaeva, 2012; Baba-zadeh et al., 2015, 2017; Guseynov et al, 2014; Moritz et al., 2016; Ramazanov et al., 2012; Suleymanov, Aliev, 1977; Hemon et al., 2012, 2013). However, there is little information about the new discovered deposits of the region, with the direct participation of the co-authors of this article (Gedabey Exploration Group - Anar Veliyev, Samir Mursalov).

The NW part in southern of Gedabey ore district has been explored for porphyry-epithermal ore perspective areas due to its favorable geological setting for Gedabey and Gadir type of deposit. In the result of exploration activities there were discovered several new local epithermal mineralization areas, one of which has underground mining, named Gadir deposit (low sulfidation type) (Baba-zadeh et al., 2015; Valiyev et al., 2016, 2018; Novruzov et al., 2019) and named Ugur exploration area Reza gold deposit (by AIMC Gedabey Exploration Group,
2014). Other ore perspective areas are in advanced stages of exploration, such as Umid, AC, Zefer and Bittibulag (Baba-zadeh et al., 2019).

Identification of exploration targets by mineral prospecting often includes reviews of available information, interpretation of remote sensing data, geological mapping and soil geochemical surveys.

This article describes Ugur exploration area - Reza gold deposit, and some mineralization areas (Gyzyldjadag, Shah Yatag, Yukhari Narzan and Dashbulag) which can be of interest from the commercial point of view in future (fig. 2).

Available information on property description and location, which is common to all the exploration projects, may be found above in the report section with that name. The following information comes largely from Gedabey Exploration Group.

A personal inspection of the Ugur Exploration Area was made by Vice President Farhang Hedjazi and Director of Geology Dr. Stephen Westhead. It was concluded that, for present purposes, Gedabey NW Project is an advanced exploration project. A substantial amount of historical and more recent exploratory work has been carried out by previous and current owners and exploration activity is ongoing.

Ugur Exploration Area is identified in the following list (Fig. 2):

- Reza gold deposit (Au-Ag); high sulfidation type;

- Gyzydjadag sulphur mineralization area (Au-Ag-S); high sulfidation type;

- Dashbulag mineralization area (Au-Ag-Cu); high sulfidation type;

- SHAH Yatag mineralization area (Au-Ag-Cu); high sulfidation type;

- Yukhari Narzan mineralization area (Au-Ag), high sulfidation type.

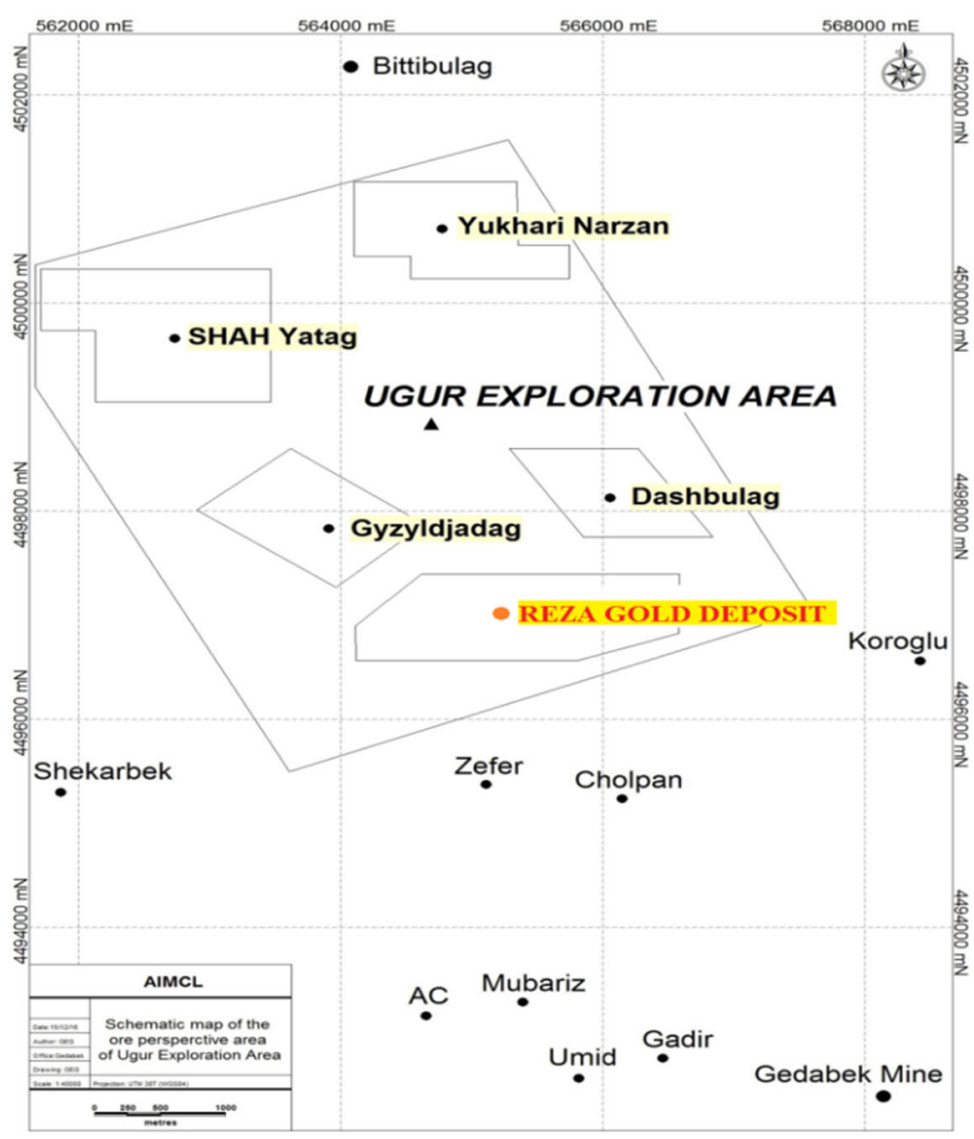

Fig. 2. Schematic map of the ore perspective area of Ugur Exploration Area 
Regional geological-structural setting. Ugur Exploration Area is located at $4 \mathrm{~km}$ to the southwest Gedabey high sulfidation epithermal deposit, on Mountain Gyzyldjadag (Fig. 3).

The Reza gold deposit, Shah Yataq, Gyzydjadag, Dashbulag and Yukhari Narzan mineralization areas are all located within on the Gedabey-Bittibulag regional deeper fault system. The major elongated structural zones within the system form the framework for the region.

Middle Jurassic to Upper Jurassic sedimentary, magmatic and metamorphic rocks forms the basement of the region. These are intruded by Upper Bajocian to Kimmeridgian age plagiogranites, gabbros, diorites, granodiorites and granites. In a geological structure of mineralization area includes Upper Bajocian rhyolite-dacites and their agglomerated tuffs and secondary quartzites of compound genesis. There are also widely developed contact hydrothermalites along with fumarole-solfatara type due to acid volcanism of Upper Bajocian Age. Contact hydrothermalites get their origin in plagiogranite intrusion exposures having wide expansion in a large field of hydrothermalites spread in the head river Djeyirchay. And a broad net of discontinued dislocations is developed on the given area where the dominant role among them belongs to Gedabey-Bittibulag deeper fault.
Within the mineralization area bounds there also observed Gyzyldjadag fault of latitudinal strike in which zone at a thickness $15 \mathrm{~m}$ the rock are brecciated, silicificated and limonitized. The area is confined to an intersection knot of above-listed faults however the dominant role in mineralization localization belongs to Gedabey-Bittibulag deeper fault (Fig. 3).

Rocks within the mineralization areas bounds, enclosed between tectonic structures, are strongly kaolinized and impregnated by phenocrysts of pyrite and rarely chalcopyrite at which leaching formed a gossan composed of strongly limonitized, ocherous rocks.

Copper minerals as rare phenocrysts of chalcopyrite and hypergene formations as malachite are observed on an intersection area of Gedabey-Bittibulag fault with Gyzyldjadag fault.

Deposit was discovered in 2016 by GEG and called Reza in honour of Reza Vaziri who is the president of Azerbaijan International Mining Company, Anglo Asian Mining PLC.

The Reza gold deposit is located in Gedabey Ore District of the Lesser Caucasus in NW of Azerbaijan, $358 \mathrm{kms}$ East of the capital city Baku, $48 \mathrm{kms}$ East of the city of Ganja and Ganja airport, 4.7 kms NW of Gedabey open-pit gold copper mine. The deposit is the well within the Ugur exploration area, NW Area polygon of Gedabey Contract Area.

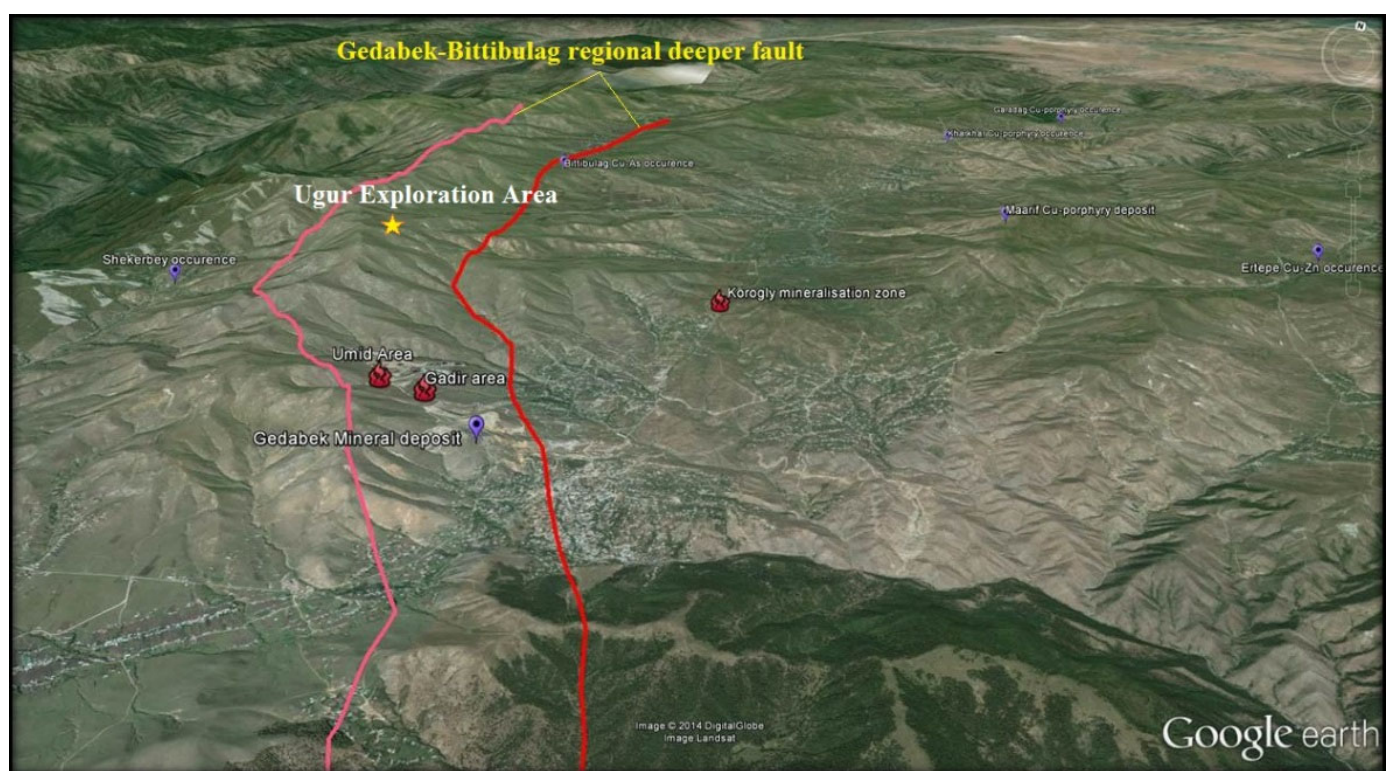

Fig. 3. Location of Ugur Exploration Area on Gedabey-Bittibulag regional deeper fault system (www.googleearth.com)

The exploration centre of the project is the partially backfilled outcrop, independently located on Google Earth at Latitude $40^{\circ} 37^{\prime} 13.10^{\prime \prime} \mathrm{N}$ and Longitude $45^{\circ} 46^{\prime} 15.34 " \mathrm{E}$. The known gold mineralization has an estimated north-south strike length of $400 \mathrm{~m}$ and a total area of approximately 20 hectares or $0.2 \mathrm{~km}^{2}$. The deposit is enlarged by highly goldsilver surface outcrop rock chip samples over an area of $2.5 \mathrm{kms}$ North-South by $2 \mathrm{kms}$ East-West, with the Reza gold deposit located on the central part.

In a geological structure of section there participated secondary quartzites being formed under the influence of Atabek-Slavyanka plagiogranite intrusion exposures observed to the north from the gold mineralization area. The area in tectonic attitude is confined to Gyzyldjadag fault of Northeastern sub-latitudinal strike $80^{\circ}$ with a vertical dip. The mineralization zone thickness within the area bounds is up to $80-120 \mathrm{~m}$.

Rocks in the alteration zone area crumpled, argillic alterated, brecciated, strongly limonitized and hematitized. Out of metallic minerals crystalline hematite was observed.
On surface intensive barite and barite-hematite vein and veinlets, also gossan zones were observed. The main mineralization zones have been sampled in three trenches at a distance up to $270 \mathrm{~m}$ by trenches \#1, \#2 and \#3 and received positive results for gold and silver. Also there have taken approximately 550 samples from outcrop \#1 and \#2.

On the main orebody at surface centre there occured secondary quartzites with vein-veinlets barite-hematite mineralization over which accumulations of hydrous ferric oxides cementing breccias of quartz and quartzites remain. And in erosion parts "reddish mass" being oxidation product of stock and stockverk hematite ores are observed. Representing typical gossans, these accumulations by the data of trenches for thickness about 5-10 m contain gold 0.3$2.0 \mathrm{ppm}$ and silver $1.0-15.0 \mathrm{ppm}$.

Surface sampling. GEG AIMCL is pleased to announce that rock chip and channel sampling has identified multiple high-grade gold mineralizations at Ugur exploration are. Following the previously reported discovery of potentially significant outcropping hematite-barite vein and breccia 
mineralization (Exploration Report, 2013-2015) at Gedabey NW Project has undertaken systematic geological mapping and rock chip and channel sampling. This sampling has delivered exceptional gold results including $4.96 \mathrm{ppm} \mathrm{Au}$ (UGA-01), 3.07 ppm Au (UGA-43) and 3.43 ppm Au (UGA200) confirming the existence of outcropping high-grade gold mineralization. The mineralization occurs within in NW subparallel structural zones within $200 \mathrm{~m}$ in the deposit and partly in the East part.

The majority of the new results are from sampling surface outcrops that occur in the centre of known high sulfidation epithermal mineralization at Reza area, and the style of mineralization indicates a potential link between known gold-rich barite-hematite vein mineralization. A total of 48 rock chips samples were collected from out cropping and sub cropping areas across three main outcrops. The majority of samples returned highly values $(30 \%$ of samples graded more than Au 0.3 ppm; see table 1 and Fig. 4). Significantly a total of 177 samples returned grades higher than $\mathrm{Au} 0.3 \mathrm{ppm}$ and 31 samples returned more than $\mathrm{Au}$ $0.99 \mathrm{ppm}$ (up to $4.96 \mathrm{ppm} \mathrm{Au}$ ).

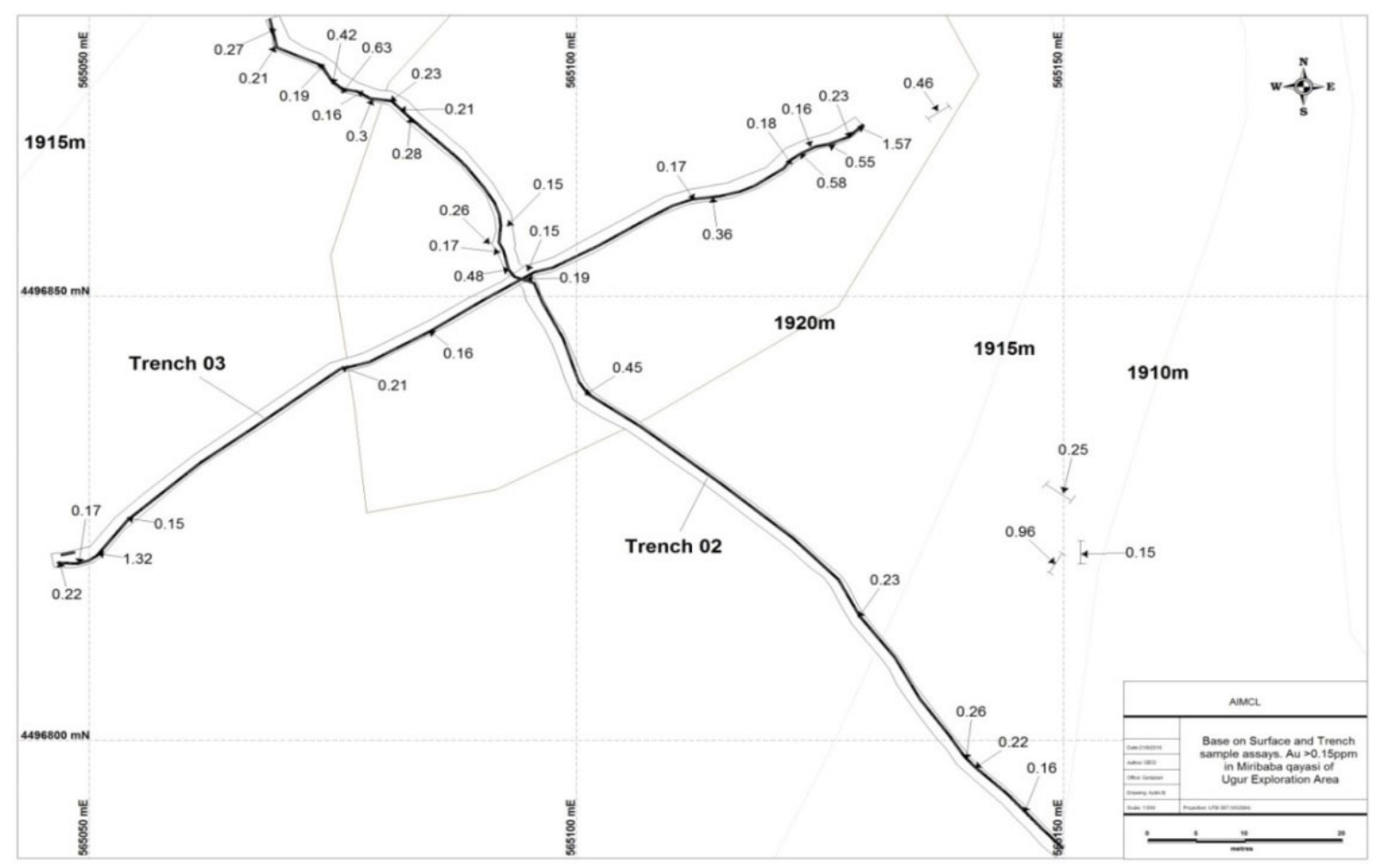

Fig. 4. Base on surface and trenches (T-2 and T-3) samples assays, Au>0.15 ppm in the Reza gold deposit of Ugur Exploration Area

Table 1

Assay results of trenches and channels sampling on the surface of Ugur Exploration area

\begin{tabular}{|c|c|c|c|c|c|c|c|}
\hline Sample_id & $\mathrm{Au}, \mathrm{ppm}$ & Ag, ppm & $\mathrm{Cu}, \%$ & $\mathrm{Zn}, \%$ & Easting & Northing & Altitude \\
\hline UGA-01 & 4.96 & 1.5 & 0.073 & 0.1069 & 565888 & 4497351 & 1691 \\
\hline UGA-30 & 0.35 & 1.3 & 0.044 & 0.0600 & 565813 & 4497325 & 1717 \\
\hline UGA-39 & 4.49 & 1.3 & 0.064 & 0.0874 & 565886 & 4497351 & 1688 \\
\hline UGA-42 & 0.67 & 1.5 & 0.034 & 0.1006 & 565958 & 4497418 & 1685 \\
\hline UGA-43 & 3.07 & 9.9 & 0.125 & 0.1375 & 565961 & 4497420 & 1685 \\
\hline UGA-44 & 2.48 & 3.5 & 0.079 & 0.0903 & 565963 & 4497421 & 1684 \\
\hline UGA-46 & 0.33 & 1.7 & 0.096 & 0.0993 & 565965 & 4497423 & 1682 \\
\hline UGA-63 & 0.56 & 1.5 & 0.116 & 0.1844 & 566148 & 4497480 & 1662 \\
\hline UGA-64 & 0.59 & 1.5 & 0.131 & 0.1387 & 566147 & 4497481 & 1662 \\
\hline UGA-65 & 0.97 & 2.1 & 0.070 & 0.1561 & 566118 & 4497459 & 1667 \\
\hline UGA-69 & 0.96 & 2.4 & 0.046 & 0.0223 & 565684 & 4497294 & 1667 \\
\hline UGA-72 & 1.37 & 2.3 & 0.037 & 0.0576 & 565658 & 4497273 & 1667 \\
\hline UGA-74 & 0.64 & 2.9 & 0.041 & 0.0374 & 565622 & 4497260 & 1667 \\
\hline UGA-75 & 1.33 & 6.6 & 0.050 & 0.0375 & 565595 & 4497262 & 1667 \\
\hline UGA-76 & 0.71 & 2.2 & 0.055 & 0.0724 & 565569 & 4497251 & 1667 \\
\hline UGA-88 & 0.29 & 7.7 & 0.053 & 0.1536 & 565310 & 4496898 & 1869 \\
\hline UGA-91 & 0.36 & 2.8 & 0.047 & 0.1277 & 565310 & 4496897 & 1869 \\
\hline UGA-92 & 0.71 & 22.1 & 0.066 & 0.2127 & 565309 & 4496897 & 1869 \\
\hline UGA-93 & 0.44 & 2.9 & 0.075 & 0.0990 & 565308 & 4496896 & 1869 \\
\hline UGA-94 & 0.34 & 5.1 & 0.055 & 0.2089 & 565308 & 4496895 & 1869 \\
\hline UGA-98 & 0.36 & 8.2 & 0.033 & 0.1403 & 565310 & 4496893 & 1875 \\
\hline UGA-99 & 0.63 & 6.3 & 0.059 & 0.1967 & 565311 & 4496892 & 1875 \\
\hline UGA-100 & 0.50 & 6.0 & 0.059 & 0.1458 & 565314 & 4496902 & 1873 \\
\hline UGA-101 & 0.44 & 7.6 & 0.060 & 0.1487 & 565311 & 4496903 & 1871 \\
\hline UGA-106 & 0.57 & 7.0 & 0.038 & 0.1107 & 565321 & 4496907 & 1867 \\
\hline UGA-107 & 0.93 & 3.9 & 0.078 & 0.1457 & 565323 & 4496908 & 1867 \\
\hline UGA-108 & 0.84 & 2.9 & 0.069 & 0.1489 & 565323 & 4496911 & 1866 \\
\hline
\end{tabular}




\begin{tabular}{|c|c|c|c|c|c|c|c|}
\hline \multicolumn{8}{|c|}{ Ending table 1} \\
\hline Sample_id & $\mathrm{Au}, \mathrm{ppm}$ & Ag, ppm & $\mathrm{Cu}, \%$ & $\mathrm{Zn}, \%$ & Easting & Northing & Altitude \\
\hline UGA-112 & 0.60 & 3.8 & 0.127 & 0.1713 & 565329 & 4496908 & 1863 \\
\hline UGA-113 & 0.32 & 4.1 & 0.160 & 0.2472 & 565330 & 4496920 & 1859 \\
\hline UGA-114 & 0.88 & 6.0 & 0.136 & 0.1357 & 565328 & 4496921 & 1858 \\
\hline UGA-115 & 1.36 & 10.3 & 0.150 & 0.2102 & 565329 & 4496928 & 1857 \\
\hline UGA-116 & 0.45 & 9.0 & 0.151 & 0.2487 & 565325 & 4496920 & 1860 \\
\hline UGA-118 & 0.99 & 2.9 & 0.086 & 0.1769 & 565334 & 4496925 & 1856 \\
\hline UGA-120 & 0.44 & 6.7 & 0.067 & 0.1425 & 565330 & 4496948 & 1850 \\
\hline UGA-124 & 0.31 & 0.9 & 0.002 & 0.0100 & 565263 & 4497029 & 1872 \\
\hline UGA-125 & 0.42 & 1.6 & 0.012 & 0.0082 & 565264 & 4497027 & 1873 \\
\hline UGA-126 & 0.65 & 1.0 & 0.016 & 0.0398 & 565264 & 4497025 & 1873 \\
\hline UGA-127 & 0.58 & 1.7 & 0.020 & 0.0256 & 565263 & 4497023 & 1873 \\
\hline UGA-128 & 0.76 & 1.0 & 0.020 & 0.0230 & 565262 & 4497022 & 1873 \\
\hline UGA-129 & 0.46 & 1.1 & 0.021 & 0.0344 & 565262 & 4497020 & 1873 \\
\hline UGA-131 & 0.71 & 1.1 & 0.016 & 0.0168 & 565261 & 4497016 & 1874 \\
\hline
\end{tabular}

Trenching. Reza gold deposit trenches were dug with the objective of discovering mineral bodies under the unconsolidated cover, sampling and ascertaining the orientation. Two main phases of trenching occurred, with the initial trenching taking place on surface of the deposit, with validation and infill trenching completed by GEG (Fig. 5).

In the aim to identify the gold presence in oxidized secondary quartzite zone on the surface 5 trenches were provided. Trenches were dug by excavator in length between 50 to $170 \mathrm{~m}$ the depth of $1.5 \mathrm{~m}$. The trenches were mapped and sampled manually by taking one-to two meter long channel samples. The samples weights ranged between 2-5 kilograms.

The main mineralization targets have been sampled in three trenches at a distance up to $270 \mathrm{~m}$ by trenches \#1, \#2 and \#3 (Fig. 4) and given good results for gold and silver.
Also approximately 350 samples from outcrop \#1 and \#2 have been taken.

Rc drilling. In the Reza gold deposit, 55 bore holes were drilled on a $50 \times 50 \mathrm{~m}$ grid (Fig. 6) (the results of the analyzes are given in table 2).

$\mathrm{RC}$ holes were drilled at an angle of -90 degrees at a diameter $146 \mathrm{~mm}$. The air-flush RC holes were intended to test the extension of the oxidized gold mineralization at depth. Slurry recovery was in the range $80-100 \%$. However, although drilling below the level of ground water is technically feasible, the slurry material is lost and enriched with heavy residues.

Fifty-five RC holes were drilled for a total of $1482 \mathrm{~m}$ to test oxide gold mineralization in the central part of the deposit, also in flanks.
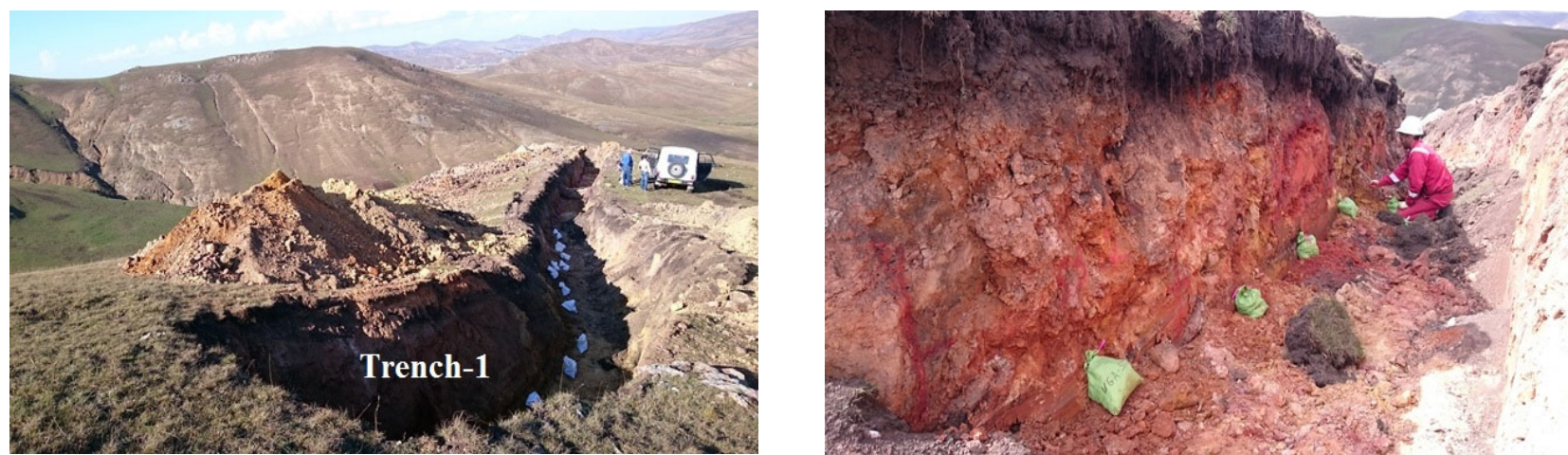

Fig. 5. Controlling of exploration surface sampling of trenches Reza gold deposit of Ugur Exploration Area

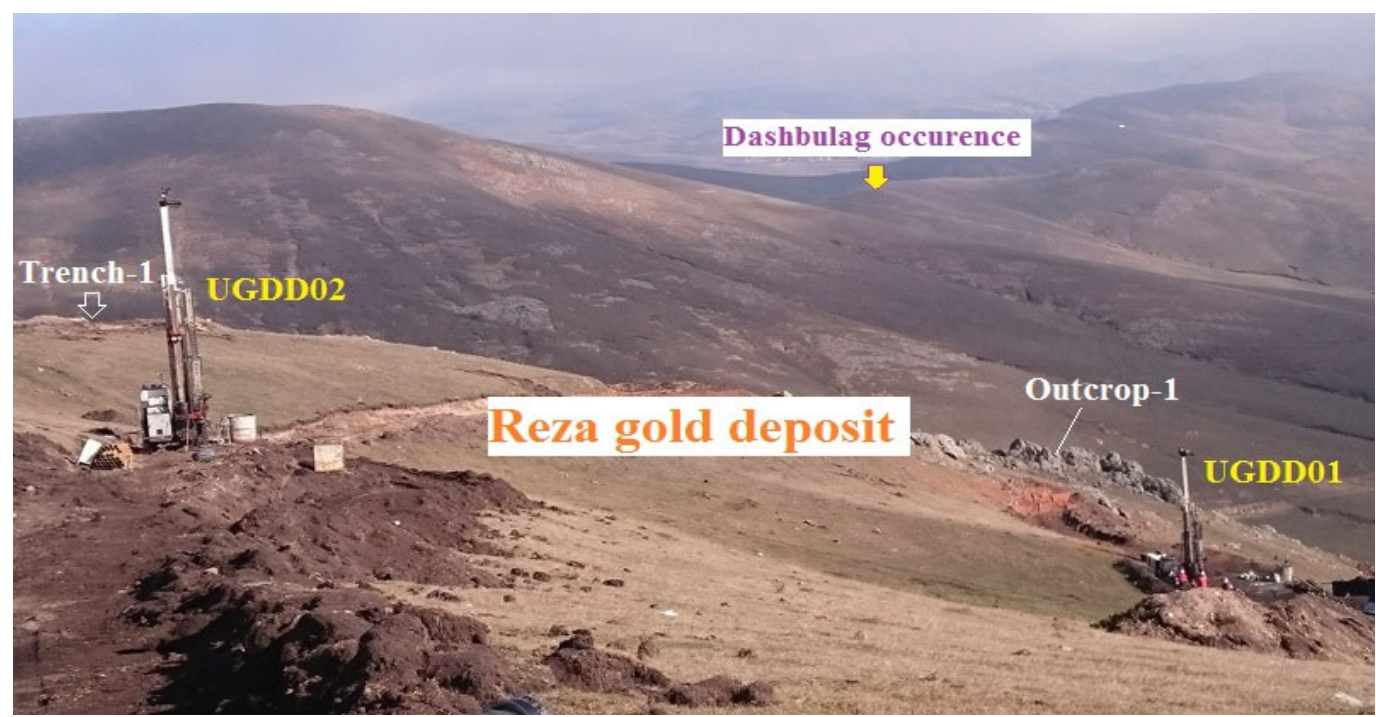

Fig. 6. Location of UGDD $01 \& 02$ bore holes at the Reza gold deposit 
Assay results of RC bore holes of Reza gold deposit, Ugur exploration area $(>0.29 \mathrm{ppm} \mathrm{Au})$

\begin{tabular}{|c|c|c|c|c|c|c|c|c|}
\hline hole_id & sample_id & from, $m$ & to, $\mathrm{m}$ & length, m & $\mathrm{Au}, \mathrm{ppm}$ & Ag, ppm & $\mathrm{Cu}, \%$ & $\mathrm{Zn}, \%$ \\
\hline UGRC̄02 & UGRC02-14 & 13 & 14 & 1 & 0.61 & 0.83 & 0.0037 & 0.0337 \\
\hline UGRC02 & UGRC02-15 & 14 & 15 & 1 & 0.50 & 1.05 & 0.0025 & 0.0296 \\
\hline UGRC02 & UGRC02-16 & 15 & 16 & 1 & 0.38 & 0.75 & 0.0036 & 0.0269 \\
\hline UGRC02 & UGRC02-20 & 18 & 19 & 1 & 0.30 & 0.75 & 0.0034 & 0.0290 \\
\hline UGRC03 & UGRC03-15 & 13 & 14 & 1 & 0.44 & 2.39 & 0.0323 & 0.2893 \\
\hline UGRC03 & UGRC03-18 & 16 & 17 & 1 & 0.89 & 11.91 & 0.0481 & 0.3271 \\
\hline UGRC03 & UGRC03-19 & 17 & 18 & 1 & 1.90 & 60.18 & 0.0356 & 0.3624 \\
\hline UGRC03 & UGRC03-20 & 18 & 19 & 1 & 1.36 & 55.77 & 0.0120 & 0.2446 \\
\hline UGRC03 & UGRC03-22 & 19 & 20 & 1 & 1.11 & 13.18 & 0.0170 & 0.2566 \\
\hline UGRC03 & UGRC03-23 & 20 & 21 & 1 & 0.98 & 23.36 & 0.0080 & 0.2487 \\
\hline UGRC03 & UGRC03-24 & 21 & 22 & 1 & 0.60 & 8.33 & 0.0223 & 0.3277 \\
\hline UGRC04 & UGRC04-3 & 5 & 6 & 1 & 1.01 & 5.56 & 0.0038 & 0.1304 \\
\hline UGRC04 & UGRC04-4 & 6 & 7 & 1 & 0.78 & 3.63 & 0.0049 & 0.1067 \\
\hline UGRC04 & UGRC04-15 & 16 & 17 & 1 & 1.89 & 9.14 & 0.0190 & 0.0835 \\
\hline UGRC04 & UGRC04-16 & 17 & 18 & 1 & 1.90 & 10.03 & 0.0246 & 0.0477 \\
\hline UGRC04 & UGRC04-17 & 18 & 19 & 1 & 2.17 & 6.76 & 0.0248 & 0.1258 \\
\hline UGRC04 & UGRC04-18 & 19 & 20 & 1 & 1.60 & 14.01 & 0.0122 & 0.1175 \\
\hline UGRC04 & UGRC04-19 & 24 & 25 & 1 & 1.93 & 7.78 & 0.0119 & 0.0601 \\
\hline UGRC04 & UGRC04-21 & 25 & 26 & 1 & 1.89 & 10.15 & 0.0292 & 0.0885 \\
\hline UGRC04 & UGRC04-22 & 26 & 27 & 1 & 2.11 & 20.78 & 0.0202 & 0.1019 \\
\hline UGRC05 & UGRC05-11 & 9 & 10 & 1 & 1.75 & 27.78 & 0.0344 & 0.0875 \\
\hline UGRC05 & UGRC05-12 & 10 & 11 & 1 & 1.62 & 71.70 & 0.0266 & 0.0718 \\
\hline UGRC14 & UGRC14-29 & 25 & 26 & 1 & 2.10 & 18.08 & 0.0130 & 0.0386 \\
\hline UGRC14 & UGRC14-30 & 26 & 27 & 1 & 3.28 & 14.90 & 0.0144 & 0.0071 \\
\hline UGRC14 & UGRC14-31 & 27 & 28 & 1 & 7.33 & 28.82 & 0.0150 & 0.0281 \\
\hline
\end{tabular}

Diamond drill holes. Ten diamond drill holes, named UGDD 01-10 were drilled in the central part of the deposit. The drill holes were sampled mainly in 1 meter lengths from the top of the hole to the bottom.

The exploratory core holes were drilled at an angle of -90 degrees at a diameter $122.6 \mathrm{~mm}(\mathrm{PQ})$ for the first $40-$ $72.5 \mathrm{~m}$. Thereafter, the bore hole diameter was $86 \mathrm{~mm}$, producing 80 or $84 \mathrm{~mm}$ diameter cores. The core samples were marked and placed into standard boxes.

Significant intervals of weighted averages greater than 0.29 gramme per tonne gold (ppm) over down hole intervals of 1 metres or greater $(>0.29 \mathrm{ppm} \mathrm{Au}$ and $>0.9 \mathrm{~m}$ ) are summarized in table 3 below. Drill hole UGDD02 was the highest grade mineralized of the program, averaging 3.52 ppm Au over a $58.5 \mathrm{~m}$ length of the drill hole (Fig. 6). Drill hole UGDD10 was the widest mineralized of the program, averaging $1.23 \mathrm{ppm}$ Au over a $106.5 \mathrm{~m}$ length of the drill hole. Other notably mineralized drill holes included UGDD01, UGDD03, UGDD04, UGDD06, UGDD07, UGDD08 and UGDD09. Drill hole UGDD05 was the least mineralized with a best intercept of $0.45 \mathrm{ppm}$ Au for 11-

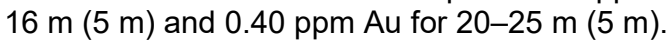

Table 3

Summary of significant drill intercepts $(>0.29 \mathrm{ppm} \mathrm{Au})$ of Reza gold deposit

\begin{tabular}{|c|c|c|c|c|c|c|c|}
\hline hole_id & sample_id & from, $\mathbf{~ m}$ & to, $\mathbf{~ m}$ & length, $\mathbf{~}$ & $\mathbf{A u}, \mathbf{p p m}$ & $\mathbf{A g}, \mathbf{p p m}$ & $\mathbf{C u}, \boldsymbol{\%}$ \\
\hline UGDD01 & UGDD01-17 & 19.00 & 20.00 & 1.00 & 0.85 & 23.58 & 0.0211 \\
\hline UGDD01 & UGDD01-18 & 20.00 & 21.00 & 1.00 & 0.75 & 18.85 & 0.0203 \\
\hline UGDD01 & UGDD01-19 & 21.00 & 22.00 & 1.00 & 1.45 & 25.25 & 0.0170 \\
\hline UGDD01 & UGDD01-20 & 22.00 & 23.00 & 1.00 & 1.09 & 19.16 & 0.0165 \\
\hline UGDD01 & UGDD01-21 & 23.00 & 24.00 & 1.00 & 1.34 & 10.66 & 0.0124 \\
\hline UGDD01 & UGDD01-33 & 34.75 & 35.50 & 0.75 & 2.81 & 8.81 & 0.0161 \\
\hline UGDD01 & UGDD01-34 & 35.50 & 36.50 & 1.00 & 5.05 & 4.69 & 0.0076 \\
\hline UGDD01 & UGDD01-35 & 36.50 & 37.50 & 1.00 & 15.87 & 1.25 & 0.0044 \\
\hline UGDD01 & UGDD01-36 & 37.50 & 38.35 & 0.85 & 5.14 & 0.97 & 0.0035 \\
\hline UGDD01 & UGDD01-37 & 38.35 & 39.15 & 0.80 & 3.19 & 1.41 & 0.0043 \\
\hline UGDD01 & UGDD01-38 & 39.15 & 40.00 & 0.85 & 2.51 & 1.01 & 0.0037 \\
\hline UGDD02 & UGDD02-04 & 4.00 & 5.00 & 1.00 & 18.45 & 31.57 & 0.0075 \\
\hline UGDD02 & UGDD02-05 & 5.00 & 6.00 & 1.00 & 13.96 & 28.83 & 0.0063 \\
\hline UGDD02 & UGDD02-06 & 6.00 & 7.00 & 1.00 & 5.33 & 16.53 & 0.0042 \\
\hline UGDD08 & UGDD08-42 & 41.00 & 42.00 & 1.00 & 17.38 & 64.74 & 0.0885 \\
\hline UGDD08 & UGDD08-43 & 42.00 & 42.50 & 0.50 & 15.38 & 53.51 & 0.0388 \\
\hline
\end{tabular}


Local geological-structural setting. The gold mineralization in the Reza deposit developed mainly during the Upper Bajocian tectonic-magmatic cycle (Fig. 7).

Tectonic zone is the main host structure for the West (central zone) and East zones of gold mineralization. During Upper Bajocian times, the central tectonic zone was a rightlateral strike-slip fault represented by a number of sub- parallel-trending faults $\left(55^{\circ}-85^{\circ}\right)$ with a combined length of $1-1.5$ kilometres. The fault dips are from $70^{\circ}$ to $80^{\circ}$ to the north-west. The faults of the central zone control the hydrothermal metasomatic alteration, gold mineralization, Upper Bajocian Atabek-Slavyanka plagiogranite massive intrusion, and in some cases are the borders of the elevated tectonic blocks formed by Lower Bajocian volcanic rocks.
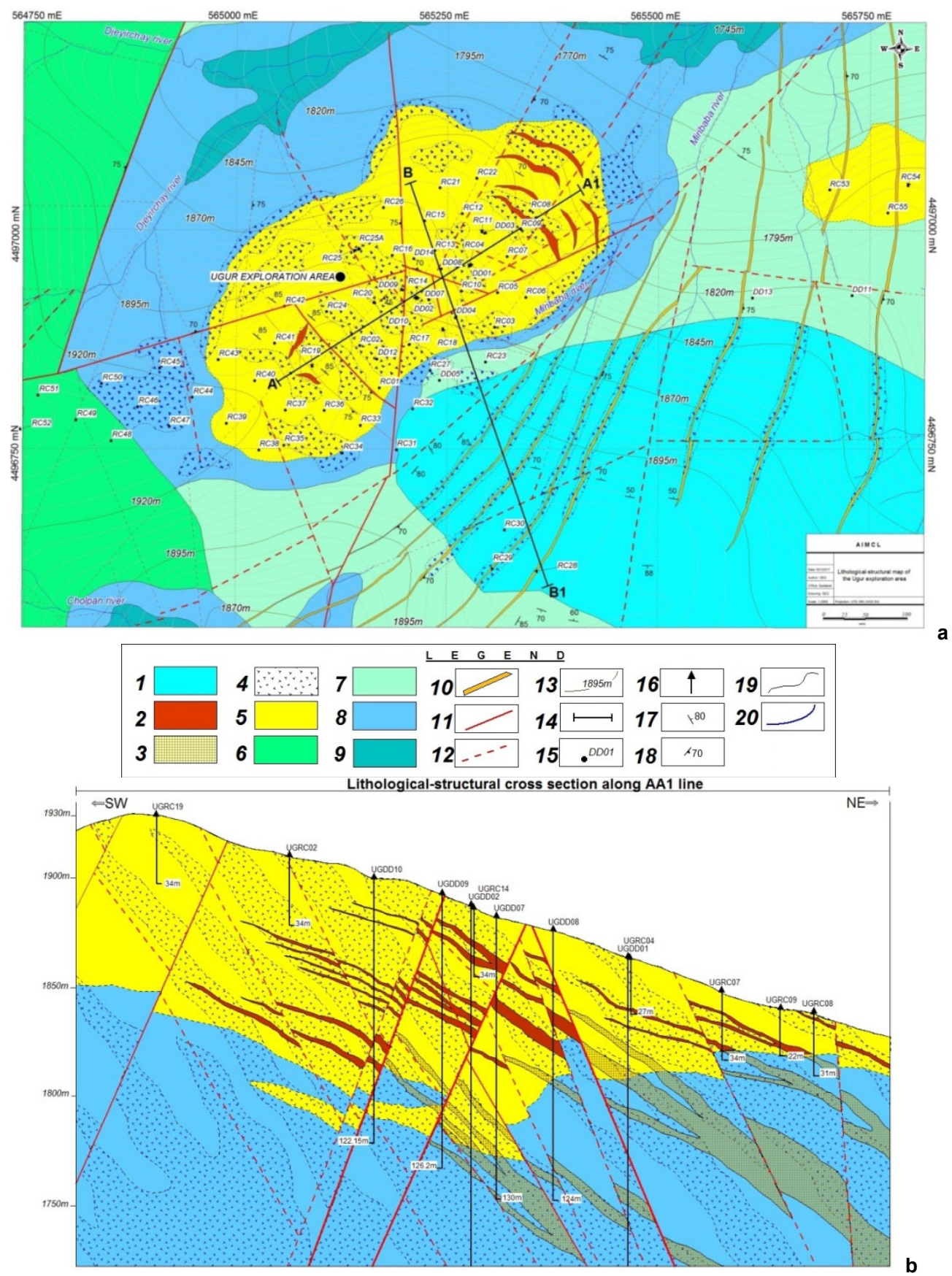

Fig. 7. Lithological-structural map (a) of the Reza gold deposit, Ugur exploration area

(scale 1:2800, A3 format, Original scale 1:1 000 (by GEG, 2016)) and lithological-structural cross section along AA1 line (b). Legend: 1 - andesite tuff agglomerates facie; 2 - gossan; 3 - pyrite stock and stockverk; 6 - breccia zone of silicified andesite porphyritic rocks; 5 - secondary quartzite; 6 - pyroclastic (from small clastic to lapilli) facie of rhyolite-dacite porphyry;

7 - lava facie of rhyolite-dacite porphyry; 8 - silicified andesite porphyritic rocks; 9 - andesite porphyritic rocks; 10 - quartz porphyry zone (weak hematitized, limonitezation); 11 - faults; 12 - probably faults; 13 - topographic contour line; 14 - cross section lines; 15 - bore holes points; 16 - bore holes ; 17 - deep angle of faults and dykes; 18 - structural elements of rocks; 19 - lithological contact; 20 - rivers

The East tectonic zone is complicated by the occurrence of numerous related faults such as antithetic and synthetic faults, down throw and thrust faults and intense folding due to faulting. The combination of these structures determines the general morphology of both the oxide and primary sulfide mineralization. Where zones of either fracture cleavage or quartz veinlets occur in drill core, these intervals are described as fault zones. In many cases the intervals of faulting are represented by tectonic breccias in which relics of the host volcanic-sedimentary rocks are cemented by dacitic rock. The tectonic breccias probably formed after emplacement of the sulfide mineralization, during the 
formation of the sub-longitudinal faults. The intervals of tectonic breccia exhibit lower gold grades in comparison with zones of fracture cleavage and quartz veinlets.

The Reza gold deposit was emplaced in the intersection of NW, NE, N and $\mathrm{E}$ trending structural systems regionally controlled by a first order NW transcurrent structure.

Structure geometry and kinematics determined from surface mapping and drilling information suggest that the volcanic sequence hosted at central part might have been accumulated in a "pull-apart" basin controlled by NW structures. These structures were affected by two compressive deformation processes: the first as a result of the $\mathrm{N}$ to the NNE sub-horizontal contraction and the second being formed during a post mineral NW contraction.

Field geological exploration information, cross-cutting relationships between structures, veins and brecciation types and hydrothermal alterations styles suggest that the mineralization was controlled by NW brittle dextral shears, associated with E-W left lateral and $\mathrm{N}-\mathrm{S}$ pure extensional structures, with all them related to the contraction event within a transpressional regimen.

Deposit type. The Gedabey NW project is a new local ore belt system discovered by GEG while following-up high priority alteration targets in a key mineralization area located in the Gedabey-Bittibulag ore belt of the Gedabey ore district in Azerbaijan. The ore belt contains a series of Jurassic-age porphyry, high-sulfidation and low-sulfidation epithermal gold deposits and mineralization occurrences. The remote sensing anomalous (in NW and SW) area is believed to remain open in all directions under shallow, post-mineral cover. Deposit alteration signature has characteristics which suggest the current outcrop level may be near the top of a mineralized, gold-bearing high sulfidation epithermal (HSE) system.

The gold mineralization at the deposit is interpreted as forming in shallow high sulfidation epithermal systems (Sillitoe, Hedenquist, 2003; Simmons, 2005; Sillitoe, 2010) . The mineralization has been noted to occur in two different styles:

- well-confined hydrothermal breccias;

- associated with pyrite stock-stockwork.

The majority of the deposit material and current estimates are formed within the barite-hematite-quartzkaoline mineralization in the secondary quartzite rocks.

The main brecciation and stockwork are hosted within secondary quartzite, sometime massive silicified andesite porphyritic rocks.

Outcropping gold mineralization in the project is oxidized with no sulfides recognised at surface. Mineralization is hosted by brecciated, and intense advanced argillically-altered andesitic volcanics and possible domes, including large areas of "powdery" probably alunite-opal alteration (Fig. 8).
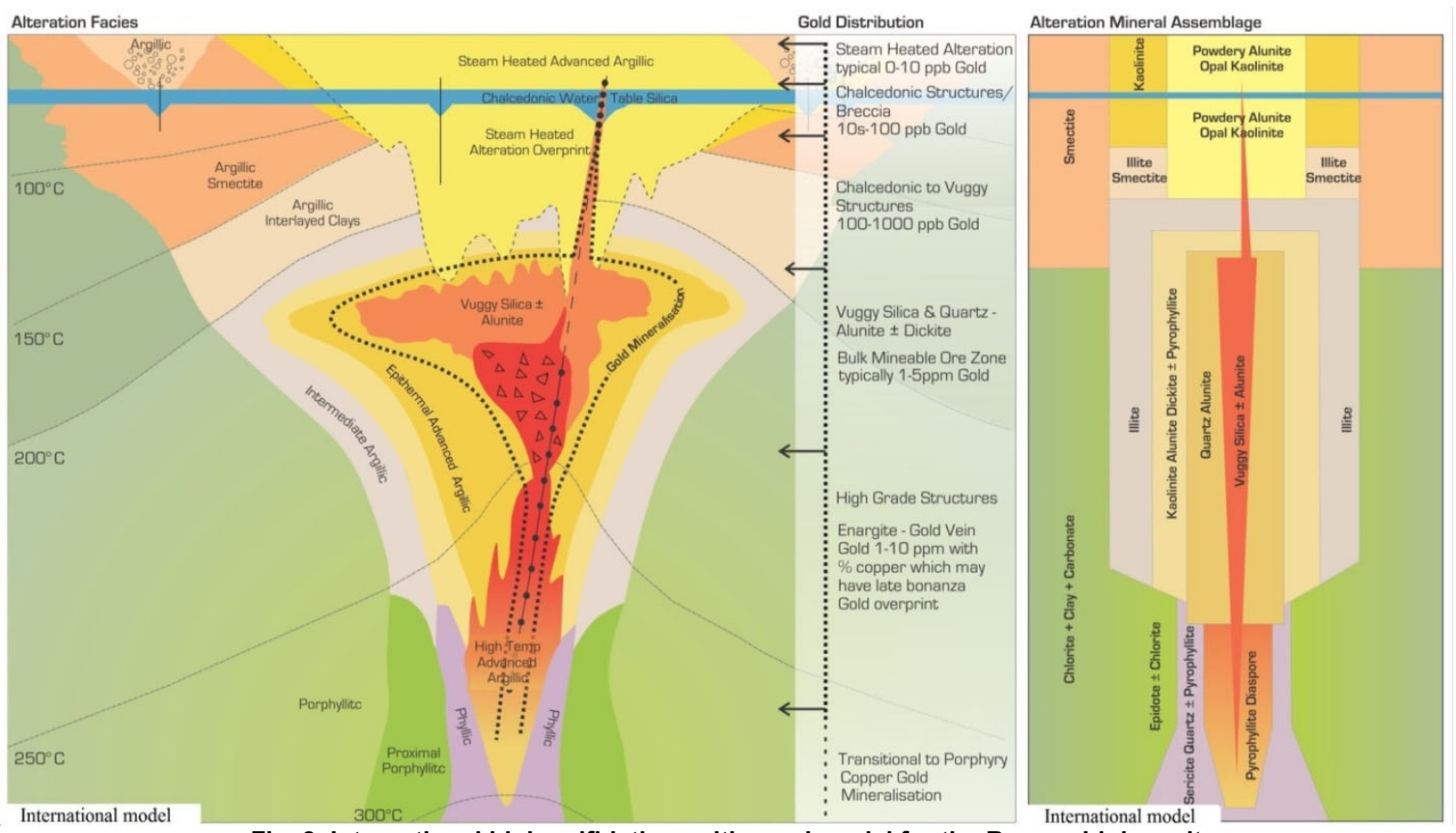

Fig. 8. International high sulfidation epithermal model for the Reza gold deposit

The outcropping alteration at the deposit is typical of the upper steam-heated levels of high-sulfidation epithermal (HSE) deposits, which in most mineralized systems of this type, may cap higher-grade gold mineralization which is hosted by underlying vuggy and oxide zones.

From our current mapping and sampling, the gold mineralization at the deposit appears to form a crescent shape surrounding a "core" of barite-hematite mineralisation in advanced argillically \& silicification altered porphyritic andesite host rock.

Recommended. The objectives and recommended methodology of the next phase of work are outlined below.

$\checkmark$ Stage 1: Re-logging of core and re-interpretation to confirm geology model. Any mineralized exposures that are open, or were undiscovered, should be systematically sampled and documented.

$\checkmark$ Stage 2: Complete a thorough review and compilation of the database. This should include re-logging of core and standardizing nomenclature for log coding. Data can then be used to build new accurate cross sections for future drill hole planning. Field checks of geologic mapping to verify structural and lithologic interpretations should be completed as warranted. An intrusive suite of samples will be collected for detail petrographic-mineralogical and fluid inclusion studies.

$\checkmark$ Stage 3: All data will be compiled for detailed drill hole planning for initial confirmation drilling. 
Список використаних джерел

Абдуллаев, Р.Н., Мустафаев, Г.В., Мустафаев, М.А. и др. (1988). Мезозойские магматические формации Малого Кавказа и связанное с ними эндогенное оруденение. Баку: Элм.

Абдуллаева, Ш.Ф. (2018). Вулканогенные золотосодержащие сульфидные месторождения островодужных зон, условия их геодинамического развития, закономерности размещения и критерии прогнозирования (Малый Кавказ). Авторефр. дис. ... д-ра наук (науки о Земле): 2520.01. Бакинский Государственный Университет, Баку.

Баба-заде, В.М. (Ред.). (2005). Минерально-сырьевые ресурсы Азербайджана. Баку: Озан

Баба-заде, В.М., Абдуллаева, Ш.Ф. (2012). Благороднометалльные рудно-магматические системы. Баку: изд. "Бакинского Университета".

Баба-заде, В.М., Имамвердиев, Н.А., Мансуров, М.И. и др. (2019). Определение гидротермально-измененных и минерализованных зон с использованием данных спутника ASTER (Кедабекский рудный район). Вестник Бакинского Университета. Серия естественных наук, 1, 69-78.

Баба-заде, В.М., Кекелия, С.А., Абдуллаева, Ш.Ф. и др. (2017). Золоторудные месторождения, условия их образования и характерные особенности геодинамического развития (Малый Кавказ). Статья I. Вестник Бакинского Университета. Серия естественных наук, 1, 83-110.

Баба-заде, В.М., Кекелия, С.А., Абдуллаева, Ш.Ф., Кекелия, М.А. (2015). Золотосодержащие сульфидные месторождения островодужных палеосистем, их металлогенические особенности и условия геодинамического развития. Баку: CBS.

Баба-заде, В.М., Кекелия, С.А., Абдуллаева, Ш.Ф., Кекелия, М.А. (2017). Рудные месторождения центрального сегмента альпийского горно-складчатого пояса и проблемы их генезиса (Большой и Малый Кавказ, Восточные Понтиды). Баку: CBS

Рамазанов, В.Г., Мориц, Р., Каландаров, Б.Г. и др. (2012). Месторождения благородных и цветных металлов Кедабекского рудного района, перспективы их поисков. Вестник Бакинского Университета. Серия естественных наук, 3, 117-133.

Сулейманов, С.М., Алиев, В.И. (1977). Фации и минеральные типы вторичных кварцитов Кедабекского рудного района. Ученые записки АГУ, сер геол.-геогр. наук, 2, 3-11.

Adamia, Sh., Zakariadze, G., Chkhotua, T. et al. (2011). Geology of the Caucasus: a review. Turkish Journal of Earth Sciences, 20, 489-544

AIMC Gedabey Exploration Group (GEG). (2014). Report about the results and future planning of the perspective areas ( $\mathrm{Au}, \mathrm{Ag}, \mathrm{Cu}, \mathrm{Mo}, \mathrm{Zn})$ of Gedabey Ore District, Gedabey.

Baba-zadeh, V.M., Mursalov, S.S., Veliyev, A.A., Imamverdiyev, N.A. et al. (2019). Geochemical anomalies in the NW flank of Gedabey mine (Lesser Caucasus, Azerbijan). International Journal of Mining Science (IJMS), 5, 1, 31-42. ISSN 2454-9460

Baba-zadeh, V.M. Veliyev, A.A. Abdullayeva, Sh.F. et al. (2015). New perspective Gadir mineralization field in Gedabey ore region. Reports of National Academy of Sciences of Azerbaijan, 2, 74-79.

Guseynov, G., Valiyev, A., Mammadov, S., Bayramov, A. (2014). Mineralization of the Gedabey gold-copper deposit, (Lesser Caucasus). 8th International Symposium on Eastern Mediterranean Geology, October 13-17, 2014, Mugla, Turkey, 116.

Hemon, P., Moritz, R., Ramazanov, V., Spangenberg, J. (2012). The Gedabey ore deposit: A Lower Cretaceous epithermal system within the Lesser Caucasus of western Azerbaijan. Society of Economic Geologists Conference, September, 2012, Lima, Peru. Abstract Volume, Poster 50.

Hemon, P., Moritz, R., Ramazanov, V. (2013). The Gedabey epithermal Cu-Au deposit, Lesser Caucasus, Western Azerbaijan: Geology, alterations, petrography and evolution of the sulfidation fluid states. Conferens on recent research activities and new results about the regional geology, the geodynamics and the metallogeny of the Lesser Caucasus. A SCOPES meeting, Tbilisi, 19-20

Moritz, R., Selby D., Popkhadze, N. et al. (2016). Metallogeny of the Lesser Caucasus: From Arc Construction to Postcollision Evolution. Society of Economic Geologists, Inc. Spesial Publication, 19, 157-192.

Novruzov, N., Valiyev, A., Bayramov, Ay. et al. (2019). Mineral composition and paragenesis of altered and mineralized zones in the Gadir low sulfidation epitermal deposit (Lesser Caucasus, Azerbaijan). Iranian Journal of Earth Sciences, II, 1, 14-29.

Sillitoe, R.H. (2010). Porphyry copper systems. Economic Geology, 105, $3-41$.

Sillitoe, R.H., Hedenquist, J.W. (2003). Linkages between volcanotectonic settings, ore-fluid compositions, and epithermal precious metal deposits. Special Publication-Society of Economic Geologists, 10, 315-343.

Simmons, S.F., White, N.C. John, D.A. (2005). Geological characteristics of epithermal precious and base metal deposits. Economic Geology, 100th Anniversary Volume, 485-522.

Valiyev, A., Bayramov, A., Mammadov, S., Mursalov, S. et al. (2016). Structural Geology, Lithology, Mineralization, and New Perspectives on the Gadir LowSulfidation Deposit, Gedabey District; a Newly Discovered Orebody in the Tethyan Metallogenic Belt, Lesser Caucasus, Azerbaijan. Society of Economic Geologists, Inc. SEG Conference, Chesme, Izmir, Turkey.

Valiyev, A., Bayramov, Ay., Ibrahimov, J. et al. (2018). Geological Setting and Ore Perspective of the New Discovered Gadir Low Sulfidation Epithermal Deposit, Gedabey NW Flank, Lesser Caucasus, Azerbaijan. Universal Journal of Geoscience, 6(3), 78-101.

\section{References}

Abdullaev, R.N., Mustafaev, G.V., Mustafaev, M.A. et al. (1988). Mesozoic igneous formations of the Lesser Caucasus and related endogenous mineralization. Baku: Elm. [in Russian]

Abdullaeva, Sh.F. (2018).Volcanogenic gold-bearing sulfide deposits of islandarc zones, conditions for their geodynamic development, patterns of distribution and forecasting criteria (Small Caucasus). Extended abstract of Doctor's thesis (Earth Sci.): 2520.01. Baku State University, Baku. [in Russian]

Adamia, Sh., Zakariadze, G., Chkhotua, T. et al. (2011). Geology of the Caucasus: a review. Turkish Journal of Earth Sciences, 20, 489-544

AIMC Gedabey Exploration Group (GEG). (2014). Report about the results and future planning of the perspective areas ( $\mathrm{Au}, \mathrm{Ag}, \mathrm{Cu}, \mathrm{Mo}, \mathrm{Zn})$ of Gedabey Ore District, Gedabey.

Baba-zadeh, V.M. (Eds.) (2005). Mineral resources of Azerbaijan. Baku: Ozan. [in Russian]

Baba-zadeh, V.M., Abdullaeva, Sh.F. (2012). Noble metal ore-magical systems. Baku: Baku University. [in Russian]

Baba-zadeh, V.M., Imamverdiyev, N.A., Mansurov, M.I. et al. (2019.). Detection of hydrothermally altered and mineralized zones using ASTER materials (Kedabek ore district). Baku University News. Series of Natural Sciences, 1, 69-78. [in Russian]

Baba-zadeh, V.M., Kekelia, S.A., Abdullaeva, Sh.F. et al. (2017). Gold ore deposits, the conditions of their formation and the characteristic features of geodynamic development (Lesser Caucasus). Article I. Baku University News. Series of Natural Sciences, 1, 83-110. [in Russian]

Baba-zadeh, V.M., Kekelia, S.A., Abdullaeva, Sh.F., Kekelia M.A. (2017). Ore deposits of the central segment of the alpine mountain-folded belt and problems of their genesis (Greater and Lesser Caucasus, East Pontids). Baku: CBS. [in Russian]

Baba-zadeh, V.M., Kekelia, S.A., Abdullaeva, Sh.F., Kekelia, M.A. (2015). Gold-bearing sulfide deposits of island-arc paleosystems, their metallogenic features and conditions of geodynamic development. Baku: CBS.

Baba-zadeh, V.M., Mursalov, S.S., Veliyev, A.A., Imamverdiyev, N.A. et al. (2019). Geochemical anomalies in the NW flank of Gedabey mine (Lesser Caucasus, Azerbijan). International Journal of Mining Science (IJMS), 5, 1, 31-42. ISSN 2454-9460

Baba-zadeh, V.M. Veliyev, A.A. Abdullayeva, Sh.F. et al. (2015). New perspective Gadir mineralization field in Gedabey ore region. Reports of National Academy of Sciences of Azerbaijan, 2, 74-79.

Guseynov, G., Valiyev, A., Mammadov, S., Bayramov, A. (2014). Mineralization of the Gedabey gold-copper deposit, (Lesser Caucasus). 8th International Symposium on Eastern Mediterranean Geology, October 13-17, 2014, Mugla, Turkey, 116

Hemon, P., Moritz, R., Ramazanov, V., Spangenberg, J. (2012). The Gedabey ore deposit: A Lower Cretaceous epithermal system within the Lesser Caucasus of western Azerbaijan. Society of Economic Geologists Conference, September, 2012, Lima, Peru. Abstract Volume, Poster 50.

Hemon, P., Moritz, R.t, Ramazanov, V. (2013). The Gedabey epithermal $\mathrm{Cu}$-Au deposit, Lesser Caucasus, Western Azerbaijan: Geology, alterations, petrography and evolution of the sulfidation fluid states. Conferens on recent research activities and new results about the regional geology, the geodynamics and the metallogeny of the Lesser Caucasus. A SCOPES meeting, Tbilisi, 19-20

Moritz, R., Selby D., Popkhadze, N. et al. (2016). Metallogeny of the Lesser Caucasus: From Arc Construction to Postcollision Evolution. Society of Economic Geologists, Inc. Spesial Publication, 19, 157-192.

Novruzov, N., Valiyev, A., Bayramov, Ay. et al. (2019). Mineral composition and paragenesis of altered and mineralized zones in the Gadir low sulfidation epitermal deposit (Lesser Caucasus, Azerbaijan). Iranian Journal of Earth Sciences, II, 1, 14-29.

Ramazanov, V.G., Moritz, R., Kalandarov, B.G. et al. (2012). Deposits of noble and non-ferrous metals of the Kedabek ore district, prospects for their searches. Baku University News. Series of Natural Sciences, 3, 117-133.

Sillitoe, R.H. (2010). Porphyry copper systems. Economic Geology, 105 3-41. [in Russian]

Sillitoe, R.H., Hedenquist, J.W. (2003). Linkages between volcanotectonic settings, ore-fluid compositions, and epithermal precious metal deposits. Special Publication-Society of Economic Geologists, 10, 315-343.

Simmons, S.F., White, N.C. John, D.A. (2005). Geological characteristics of epithermal precious and base metal deposits. Economic Geology, 100th Anniversary Volume, 485-522.

Suleymanov, S.M., Aliev, V.I. (1977). Facies and mineral types of secondary quartzites of the Kedabek ore district. Uchenye Zapiski ASU. Series geol.-geogr. Sciences, 2, 3-11. [in Russian]

Valiyev, A., Bayramov, A., Mammadov, S., Mursalov, S. et al. (2016). Structural Geology, Lithology, Mineralization, and New Perspectives on the Gadir Low-Sulfidation Deposit, Gedabey District; a Newly Discovered Orebody in the Tethyan Metallogenic Belt, Lesser Caucasus, Azerbaijan. Society of Economic Geologists, Inc. SEG Conference, Chesme, Izmir, Turkey

Valiyev, A., Bayramov, Ay., Ibrahimov, J. et al. (2018). Geological Setting and Ore Perspective of the New Discovered Gadir Low Sulfidation Epithermal Deposit, Gedabey NW Flank, Lesser Caucasus, Azerbaijan. Universal Journal of Geoscience, 6(3), 78-101.

Надійшла до редколегії 12.01.21 
Н. Імамвердієв ${ }^{1}$, д-р геол.-мінералог. наук, проф.,

E-mail: inazim17@yahoo.com;

В. Баба-заде ${ }^{1}$, д-р геол.-мінералог. наук, проф., академік НАН Азербайджану,

E-mail: vbabazade1938@mail.ru

С. Мурсалов ${ }^{2}$, горний геолог,

E-mail: samir.m.s@mail.ru;

А. Валісв², PhD (науки про Землю), гол. геолог,

E-mail: velizade_anar@yahoo.com;

М. Мансуров ${ }^{1}$, канд. геол.-мінералог. наук, доц.

E-mail: mamoy_mansurov@mail.ru;

А. Iсмаїлова', $\overline{\mathrm{PhD}}$ (науки про Землю), доц.,

E-mail: aygun46 @mail.ru;

'Бакинський державний університет, вул. 3. Халилова, 23, м. Баку, Az 1148, Азербайджан;

${ }^{2}$ Азербайджанська міжнародна рудна компанія, м. Баку, Азербайджан

\section{ПЕРСПЕКТИВИ ОСВОЄННЯ НОВОГО РУДНОГО ВУЗЛА УГУР НА ПІВНІЧНОМУ ЗАХОДІ КЕДАБЕКСЬКОГО РУДНОГО РАЙОНУ (МАЛИЙ КАВКАЗ, АЗЕРБАЙДЖАН)}

Описано рудний вузол Угур, розташований на північному заході Кедабекського рудного району Малого Кавказу в республіці Азербайджан. Наведено результати аналізу проб, відібраних з відкритих гірничих виробок (траншей, канав), зі свердловин, пробурених методом $R C$, а також зведені дані про рудні перетини із значущим вмістом золота (>0,29 ррт). Встановлено, що площа рудного вузла може бути збільшена за рахунок високих вмістів золота і срібла в бороздовій і штуфних пробах на 2,5 км у широтному $і$ на 2 км у довготному напрямках; при цьому золоторудне родовище Реза приурочено до центральної частини рудного вузла. 3 рудних мінералів присутній кристалічний гематит. Ближче до земної поверхні спостерігаються інтенсивні баритові і барит-еематитові прожилки, а також зустрічається залізний капелюх сульфідних покладів. У ході розвідувального випробування головних зон мінералізації, розкритих траншеями № 1, 2, 3, які розташовані на відстані до 270 м одна від одної, у відібраних зразках було виявлено промислові вмісти золота срібла. Також було відібрано близько 550 зразків з оголень № 1 i № 2. У місиях виходу основного рудного тіла на денну поверхню спостерігаються вторинні кварцити з барит-гематитовими прожилками, над якими збереглися скупчення гідроксидів заліза, що цементують брекчії квариу і кварцитів. А на ділянках з інтенсивно виявленим вивітрюванням зустрічається "червона маса", що є продуктом окиснення гематитових штоків і штокверків. Являючи собою типові залізні капелюхи сульфідних покладів, ці, розкриті в канавах, рудні скупчення, мають потужність близько 5-10 м з вмістом золота 0,3-2,0 ррт і срібла 1,0-15,0 ppm. У центральній частині родовища було пробурено алмазним бурінням десять свердловин (UGDD 01-10). Свердловини випробовувалися цілком і безперервно, а довжини проб в основному становили 1 метр.

Значущі інтервали з довжинами проб 1 м і більше та із середньозваженими вмістами, що перевищують 0,29 рpm (>0,29 ppm i >0,9 м), узагальнено в таблиці. Зроблено висновок про те, що характер навколорудних гідротермально-метасоматичних змін вмісних порід, що зустрічається на даному родовищі, типовий для верхніх рівнів високосульфідних епітермальних родовищ, що зазнали оброку паром. Даний тип гідротермальних змін у більшості рудних систем може перекривати інтервали з кавернозними і оксидними зонами, що містять більш багату золоторудну мінералізацію.

Ключові слова: рудний вузол Уеур; зони мінералізації; вміст золота, срібла, міді, цинку; Кедабекський рудний район; Малий Кавказ.

Н. Имамвердиев ${ }^{1}$, д-р геол.-минералог. наук, проф.,

E-mail: inazim17@yahoo.com;

В. Баба-заде ${ }^{1}$, д-р геол.-минералог. наук, проф., акад. НАН Азербайджана,

E-mail: vbabazade1938@mail.ru

С. Мурсалов ${ }^{2}$, горный геолог,

E-mail: samir.m.s@mail.ru;

А. Валиев ${ }^{2}, \mathrm{PhD}$ (науки о Земле), гл. геолог,

E-mail: velizade_anar@yahoo.com;

М. Мансуров ${ }^{1}$, канд. геол.-минералог. наук, доц,

E-mail: mamoy_mansurov@mail.ru;

А. Исмаилова 1 , PhD (науки о Земле), доц.

E-mail: aygun46@mail.ru;

${ }^{1}$ Бакинский государственный университет, ул. 3. Халилова, 23, г. Баку, Az 1148, Азербайджан

${ }^{2}$ Азербайджанская международная рудная компания, r. Баку, Азербайджан

\section{ПЕРСПЕКТИВЫ ОСВОЕНИЯ НОВОГО РУДНОГО УЗЛА УГУР НА СЕВЕРО-ЗАПАДЕ КЕДАБЕКСКОГО РУДНОГО РАЙОНА (МАЛЫЙ КАВКАЗ, АЗЕРБАЙДЖАН)}

Описан рудный узел Угур, расположенный на северо-западе Кедабекского рудного района Малого Кавказа в республике Азербайджан. Приведены результаты анализа проб, отобранных из открытых горных выработок (траншей, канав), из скважин, пробуренных методом $R C$, а также сводные данные о рудных пересечениях со значимыми содержаниями золота (>0,29 ррт). Установлено, что площадь рудного узла может быть увеличена за счет высоких содержаний золота и серебра в бороздовых и штуфных пробах на 2,5 км в широтном и на 2 км в долготном направлениях; при этом золоторудное месторождение Реза приурочено к центральной части рудного узла. Из рудных минералов присутствует кристаллический гематит. Ближе к земной поверхности наблюдаются интенсивные баритовые и барит-гематитовые прожилки, а также встречается железная шляпа сульфидных залежей. В ходе разведочного опробования главных зон минерализации, вскрытых траншеями № 1, 2, 3, находящихся на расстоянии до 270 м друг от друга, в отобранных образцах были выявлень промышленные содержания золота и серебра. Также было отобрано около 550 образцов из обнажений № 1 и № 2 . В местах выхода основного рудного тела на дневную поверхность наблюдаются вторичные кварциты с барит-гематитовыми прожилками, над которыми сохранились скопления гидрооксидов железа, цементирующих брекчии кварца и кварцитов. А на участках с интенсивно проявленным выветриванием встречается "красноватая масса", являющаяся продуктом окисления гематитовых штоков и штокверков. Представляя собой типичные железные шляпы сульфидных залежей, эти, вскрытые в канавах, рудные скопления имеют мощность около 5-10 м с содержаниями золота 0,3-2,0 ppm и серебра 1,0-15,0 ppm. В центральной части месторождения были пробурены алмазным бурением десять буровых скважин (UGDD 01-10). Скважины опробовались целиком и непрерывно, а длины проб в основном составляли 1 метр.

Значимые интервалы с длинами проб в 1 м и более и со средневзвешенными содержаниям, превышающими 0,29 ррт (>0,29 ррт и >0,9 м), обобщены в таблице Сделан вывод о том, что характер околорудных гидротермально-метасоматических изменений вмещающих пород, встречающийся на данном месторождении, типичен для подвергшихся обработке паром верхних уровней высокосульфидных эпитермальных месторождений. Данный тип гидротермальных изменений в большинстве рудных систем может перекрывать интервалы с кавернозными и оксидными зонами, содержащими более богатую золоторудную минерализацию.

Ключевые слова: рудный узел Угур; зоны минерализации; содержание золота, серебра, меди, цинка; Кедабекский рудный район; Малый Кавказ. 